\title{
Phosphatidylinositol-4,5-Bisphosphate Regulates NMDA Receptor Activity through $\alpha$-Actinin
}

\author{
Ioannis E. Michailidis, ${ }^{1}$ Thomas D. Helton, ${ }^{2}$ Vasileios I. Petrou, ${ }^{1}$ Tooraj Mirshahi, ${ }^{1}$ Michael D. Ehlers,,${ }^{2,3}$ and \\ Diomedes E. Logothetis ${ }^{1}$ \\ ${ }^{1}$ Department of Molecular Physiology and Biophysics, Mount Sinai School of Medicine, New York, New York 10029, and ${ }^{2}$ Department of Neurobiology and \\ ${ }^{3}$ Howard Hughes Medical Institute, Duke University Medical Center, Durham, North Carolina 27710
}

\begin{abstract}
Phosphatidylinositol-4,5-bisphosphate $\left(\mathrm{PIP}_{2}\right)$ has been shown to regulate many ion channels, transporters, and other signaling proteins, but it is not known whether it also regulates neurotransmitter-gated channels. The NMDA receptors (NMDARs) are gated by glutamate and serve as a critical control point in synaptic function. Here we demonstrate that $\mathrm{PIP}_{2}$ supports NMDAR activity. In Xenopus oocytes, overexpression of phospholipase $\mathrm{C} \gamma$ (PLC $\gamma$ ) or preincubation with $10 \mu \mathrm{M}$ wortmannin markedly reduced NMDA currents. Stimulation of the epidermal growth factor receptor (EGFR) promoted the formation of an immunocomplex between PLC $\gamma$ and NMDAR subunits. Stimulation of EGFR or the PLC $\beta$-coupled $\mathrm{M}_{1}$ acetylcholine receptor produced a robust transient inhibition of NMDA currents. Wortmannin application blocked the recovery of NMDA currents from the inhibition. Using mutagenesis, we identified the structural elements on NMDAR intracellular tails that transduce the receptor-mediated inhibition, which pinpoint to the binding site for the cytoskeletal protein $\alpha$-actinin. Mutation of the $\mathrm{PIP}_{2}$-binding residues of $\alpha$-actinin dramatically reduced NMDA currents and occluded the effect of EGF. Interestingly, EGF or wortmannin affected the interaction between NMDAR subunits and $\alpha$-actinin, suggesting that this protein mediates the effect of $\mathrm{PIP}_{2}$ on NMDARs. In mature hippocampal neurons, expression of the mutant $\alpha$-actinin reduced NMDA currents and accelerated inactivation. We propose a model in which $\alpha$-actinin supports NMDAR activity via tethering their intracellular tails to plasma membrane PIP 2 . Thus, our results extend the influence of $\mathrm{PIP}_{2}$ to the NMDA ionotropic glutamate receptors and introduce a novel mechanism of "indirect" regulation of transmembrane protein activity by $\mathrm{PIP}_{2}$.
\end{abstract}

Key words: NMDA; PIP 2 ; $\alpha$-actinin; PLC; oocytes; neurons

\section{Introduction}

The importance of glutamate receptors and particularly of the NMDA subtype is widely accepted. The NMDA receptor (NMDAR) antagonist D-AP-5 has neuroprotective and anticonvulsant properties, and $\mathrm{Ca}^{2+}$ entering cells through NMDARs plays important roles in development and plasticity processes underlying learning and memory (Dingledine et al., 1999). NMDARs have been implicated in schizophrenia, epilepsy, ischemic brain damage, and neurodegenerative disorders. Thus, NMDARs are a major target for drug design (Dingledine et al., 1999; Holden, 2003; Konradi and Heckers, 2003).

Homeostatic control of the $\mathrm{Ca}^{2+}$ entering through NMDARs

\footnotetext{
Received 0ct. 6, 2006; revised Feb. 21, 2007; accepted March 27, 2007.

We are thankful to Dr. John Woodward (Medical University of South Carolina, Charleston, SC) for the clones of NR1, NR2A, NR2B, NR2C, and $\alpha$-actinin 2 and to Haiwei Zhang for excellent technical assistance. We thank Drs. Steven Siegelbaum (Howard Hughes Medical Institute, Columbia University, New York, NY), Ottavio Arancio (Department of Pathology, Columbia University, New York, NY), and Ricardo Araneda (University of Maryland, College Park, MD) for critical reading of this manuscript and Drs. Hailin Zhang (Hebei Medical University, Shijiazhuang, China) and Jin Liang Sui (CombinatoRx, Cambridge, MA) for helpful discussions as well as technical and experimental guidance.

Correspondence should be addressed to Diomedes E. Logothetis, Department of Molecular Physiology and Biophysics, Mount Sinai School of Medicine, New York, NY 10029. E-mail: diomedes.logothetis@mssm.edu.

I. E. Michailidis's present address: Department of Biological Sciences, Columbia University, New York, NY 10027.

T. Mirshahi's present address: Weis Center for Research, Geisinger Clinic, Danville, PA 17822

D0I:10.1523/JNEUROSCI.4378-06.2007

Copyright $\odot 2007$ Society for Neuroscience $\quad$ 0270-6474/07/275523-10\$15.00/0
}

is of paramount importance. Several converging modulatory inputs adjust NMDAR activity. NMDAR phosphorylation is an important mechanism regulating synaptic function. NMDARs can be phosphorylated by kinases, such as protein kinase A (Leonard and Hell, 1997), cyclin-dependent kinase (Li et al., 2001), myosin light chain kinase (Lei et al., 2001), and calcium/ calmodulin-dependent kinase II (CaMKII) (Omkumar et al., 1996). PKC activation enhances NMDA currents in neuronal preparations (MacDonald et al., 2001) as well as Xenopus oocytes (Lan et al., 2001). Protein phosphatases 1 and 2A (Wang et al., 1994) or calcineurin (Lieberman and Mody, 1994) can dephosphorylate NMDARs to downregulate activity. Tyrosine kinases and phosphatases can also adjust activation properties of NMDARs: Src application increases NMDA currents in neurons, and inhibition of endogenous tyrosine phosphatases in patches mimics this effect by increasing NMDAR open probability (Wang and Salter, 1994). NMDAR glycine-dependent (Mayer et al., 1989) and glycine-independent (Sather et al., 1990) desensitization may also regulate synaptic currents. Finally, activitydependent inactivation by $\mathrm{Ca}^{2+}$ ions (Legendre et al., 1993) results from the $\mathrm{Ca}^{2+}$-stimulated competitive displacement of the actin-crosslinking protein $\alpha$-actinin by calmodulin from the $\mathrm{C}$ termini of NR1 and NR2B, causing channel self-closure (Ehlers et al., 1996; Zhang et al., 1998; Krupp et al., 1999).

Along the lines of the complex regulation described above, the 
intracellular domains of NMDARs bind a variety of proteins. NMDARs have been shown to assemble into large multiprotein complexes together with scaffolding, cytoskeletal, and other signaling proteins (Husi et al., 2000). The relative amounts of these proteins and NMDAR subunits tightly depend on synaptic activity and fine-tune NMDAR signaling to feedback on synaptic function (Ehlers, 2003). The effects of some of these proteins, such as Src, calmodulin, and $\alpha$-actinin, are relatively well studied. However, the functional roles for several other members of these complexes, such as phospholipase C $\gamma$ (PLC $\gamma$ ), the enzyme that catalyzes the hydrolysis of phosphatidylinositol-4,5-bisphosphate $\left(\mathrm{PIP}_{2}\right)$ (Gurd and Bissoon, 1997), remain unknown.

$\mathrm{PIP}_{2}$ is an inositol phospholipid with critical roles in various cellular processes (Toker, 1998). PIP $_{2}$ directly binds and modulates various trafficking proteins and ion channels. $\mathrm{PIP}_{2}$ hydrolysis by PLC-coupled pathways regulates ion channel activity in both native and recombinant systems (Suh and Hille, 2005). Given the widespread role of $\mathrm{PIP}_{2}$ in ion channel regulation, we set out to study the effect of $\mathrm{PIP}_{2}$ on NMDARs. We show that $\mathrm{PIP}_{2}$ depletion inhibits NMDA currents and thus suggests a functional role for PLC $\gamma$, which coimmunoprecipitates with the NR1 subunit in our system. We find that this novel regulation by PLC $\gamma$ is sensed by the NMDAR via the same sites known to interact with $\alpha$-actinin and that a $\mathrm{PIP}_{2}$-dependent change in the interaction of the channel with this protein can regulate activity in a novel manner.

\section{Materials and Methods}

Oocyte preparation. Stage V or VI of Xenopus laevis (African clawed frog) oocytes were surgically removed from ovaries and digested with collagenase using standard methods (Logothetis et al., 1992). Oocytes were kept at $17^{\circ} \mathrm{C}$ in OR2 solution supplied with $\mathrm{Ca}^{2+}$.

Oocyte electrophysiological recordings. cDNAs of rat NMDAR subunits NR1 (full-length splice variant), NR2A, NR2B, and NR2C and of epidermal growth factor receptor (EGFR), $\mathrm{M}_{1}, \operatorname{PLC} \gamma$, and $\alpha$-actinin 2 were subcloned into the high-expression vector pGEMsH (Rohacs et al., 2003). cRNAs were prepared using the Ambion (Austin, TX) in vitro transcription kit and were microinjected to Xenopus laevis oocytes $(\sim 20$ ng total mRNA/oocyte). Recordings were performed 1-3 d after injection using a Dagan (Minneapolis, MN) two-electrode voltage-clamp amplifier, and currents were obtained with a square pulse protocol (pClamp software; Molecular Devices, Union City, CA). Bath solution (Ringer's solution) contained the following (in mM): $115 \mathrm{NaCl}, 2.5 \mathrm{KCl}, 1.8 \mathrm{BaCl}_{2}$, and 10 HEPES, pH 7.2. Rapid solution exchange was achieved with a gravity flow perfusion system converging on a $6 \mu$ l oocyte chamber engineered in the laboratory from inert materials. Wortmannin and phalloidin were from Sigma (St. Louis, MO), and thapsigargin was from Calbiochem (San Diego, CA). Preincubation with wortmannin (1-2 h, $10 \mu \mathrm{M}$ ) was performed in OR2 (Goldin, 1992). For thapsigargin preincubations, $\mathrm{Ca}^{2+}$-free OR2 supplied with $1 \mathrm{~mm}$ EGTA was used. For injections during the course of recordings, $\sim 50 \mathrm{nl}$ of a $50 \mu \mathrm{g} / \mu \mathrm{l}$ neomycin trisulfate stock in ND96K were injected into oocytes expressing $\mathrm{NR} 1 / 2 \mathrm{~A}(\sim 10 \mathrm{ng}$ total mRNA/oocyte) using an automatic nanoliter injector (World Precision Instruments, Sarasota, FL). Internal oocyte solution (ND96K) contained the following (in mM): $96 \mathrm{KCl}, 1 \mathrm{MgCl}_{2}, 1.8$ $\mathrm{CaCl}_{2}$, and 10 HEPES-K, pH 7.4. Neomycin trisulfate was from Sigma. To calculate the final intracellular concentration of neomycin trisulfate, we assumed that the total intracellular volume of the oocyte is $\sim 500 \mathrm{nl}$.

Hippocampal neuron electrophysiology. Whole-cell patch-clamp recordings were performed on 17-24 d in vitro rat hippocampal neurons cultured at high density on polylysine-coated glass coverslips using previously described methods (Scott et al., 2001). Neurons were transfected with enhanced green fluorescent protein (EGFP), $\alpha$-actinin wild-typeEGFP (N-terminally tagged), $\alpha$-actinin R172Q-K184Q-EGFP, pleckstrin homology $(\mathrm{PH})$ domain-EGFP (N-terminally tagged), or $\mathrm{PH}^{*}-$ EGFP (mutant R40L) constructs as indicated using Lipofectamine 2000
(Invitrogen, Carlsbad, CA) $2 \mathrm{~d}$ before recordings. Neurons were held at -60 mV using a MultiClamp 700A amplifier (Molecular Devices) controlled with a Pentium personal computer running MultiClamp Commander and pClamp software (Molecular Devices). The extracellular solution contained the following (in $\mathrm{mM}$ ): $150 \mathrm{NaCl}, 5 \mathrm{KCl}, 10 \mathrm{HEPES}$, $0.1 \mathrm{MgCl}_{2}, 30 \mathrm{D}$-glucose, $2 \mathrm{CaCl}_{2}, 0.001 \mathrm{TTX}, 0.03$ bicuculline, and 0.02 CNQX, pH 7.3 (330 mOsm/L). Recording pipettes, with resistances between 3 and $5 \mathrm{M} \Omega$, were filled with a solution containing the following (in mM): $30 \mathrm{CsSO}_{4}, 70 \mathrm{~K}_{2} \mathrm{SO}_{4}, 25 \mathrm{HEPES}, 25 \mathrm{~N}$-methyl-D-glucamine, 0.1 $\mathrm{CaCl}_{2}, 1$ EGTA, $2 \mathrm{Na}_{2} \mathrm{ATP}$, and 0.1 leupeptin, pH 7.3 (300 mOsm/L). A modified recording pipette with a narrow aperture was filled with extracellular recording solution supplemented with NMDA and glycine to concentrations of 0.1 and $0.01 \mathrm{~mm}$, respectively, and dyed with green food coloring to visualize drug application. During constant bath perfusion of $\sim 0.5 \mathrm{ml} / \mathrm{min}, \mathrm{NMDA} /$ glycine agonist solution was puffed onto the soma of the voltage-clamped neuron for $3 \mathrm{~s}$ using a Femtojet perfusion system (Eppendorf, Westbury, NY), with application initiated by a control stimulus from the pClamp software. Complete inactivation typically occurred within $3 \mathrm{~s}$. For $\mathrm{K}^{+}$channel recordings, after NMDA/ glycine application, clamped cells were held at $-80 \mathrm{mV}$, and $\mathrm{K}^{+}$currents were obtained by stepping to $0 \mathrm{mV}$. All currents were sampled at $10 \mathrm{kHz}$ and low-pass filtered at $2 \mathrm{kHz}$, and data were analyzed with Clampfit 9.2 software (Molecular Devices). Desensitization time constants were obtained with single-exponential fits to the data.

Western immunoblotting. Twenty-five to 50 oocytes for each experimental group were pretreated with $1 \mu \mathrm{M}$ thapsigargin in OR2-EGTA for $2 \mathrm{~h}$ or in $10 \mu \mathrm{M}$ wortmannin or vehicle DMSO and then stimulated with EGF when applicable (4 min, $100 \mathrm{ng} / \mathrm{ml}$; Invitrogen) in PBS supplied with phosphatase inhibitors $\left(10 \mathrm{~mm} \mathrm{NaVO}_{4}\right.$ and $\left.10 \mathrm{~mm} \mathrm{NaF}\right)$. The oocytes were then manually lysed in $1 \mathrm{ml}$ of cold lysis buffer (in mM: 5 Tris-HCl, 1 EDTA, 1 EGTA, $10 \mathrm{NaVO}_{4}$, and $10 \mathrm{NaF}$ ), supplied with protease inhibitor cocktail (Sigma), and centrifuged for $5 \mathrm{~min}$ at $5000 \times$ $g$ at $4^{\circ} \mathrm{C}$. The supernatant was then centrifuged at $100,000 \times g$ for $30-40$ $\min$ at $4^{\circ} \mathrm{C}$. The pellets were resuspended with a suitable volume of lysis buffer, and SDS-PAGE was performed, followed by electrotransfer of proteins onto a polyvinylidene difluoride membrane using the wet transfer method (Bio-Rad, Hercules, CA). The membrane was then blocked in TBS- $-1 \%$ Tween 20 supplied with $5 \%$ nonfat dry milk or $10 \%$ newborn calf serum (Invitrogen), and, after primary and secondary antibody incubation, proteins were detected by an HRP-catalyzed chemiluminescence reaction (Pierce, Rockford, IL). The antibodies were purchased from the following companies: PLC $\gamma$ from Cell Signaling Technology (Danvers, MA), $\alpha$-actinin from Sigma, and anti-NR1 from Millipore (Billerica, MA).

Immunoprecipitation. Pellets obtained as described above were resuspended in $200 \mu \mathrm{l}$ of lysis buffer containing 1\% Triton X-100 and antibody (1-5 $\mu$ g of IgG) and were incubated with gentle rocking overnight at $4^{\circ} \mathrm{C}$. Protein $\mathrm{A}$ agarose beads $(20 \mu \mathrm{l}$ of $50 \%$ bead slurry equilibrated in lysis buffer; Pierce) were added, and the samples were incubated with gentle rocking for $2 \mathrm{~h}$ at $4^{\circ} \mathrm{C}$. Samples were then microcentrifuged for 1 $\mathrm{min}$, and the pellets were washed one time with immunoprecipitation buffer, one time with lysis buffer supplied with $150 \mathrm{~mm} \mathrm{NaCl}$, and three times with lysis buffer. The beads were subjected to SDS-PAGE and Western blotting, as described above.

Mutagenesis. NR1 deletion mutants were constructed using the spliceby-overlap method to remove the targeted cDNA segment. For NR2 subunit deletion mutants, stop codons were introduced by point mutations at the positions indicated in the text and figures. Point mutations were introduced using the Stratagene (La Jolla, CA) mutagenesis kit and custom primers with nucleotide mismatches (Invitrogen) and were confirmed by sequencing (Mount Sinai Sequencing Facility). cRNAs were transcribed using an in vitro transcription kit with the T7 promoter (Ambion).

\section{Results}

To test the effects of $\mathrm{PIP}_{2}$ on NMDAR function, we used the Xenopus oocyte system, in which the $\mathrm{PIP}_{2}$ dependence of several other ion channel proteins has been studied. Using NR1/2A heteromers, we normally obtained robust responses during applica- 
A

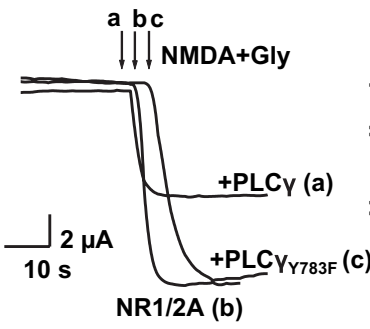

B

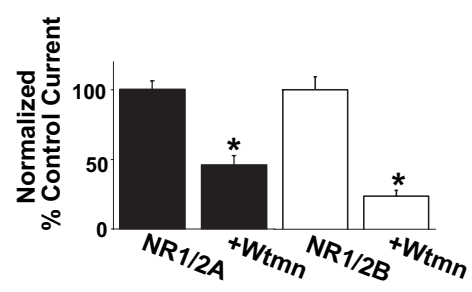

Figure 1. PLC $\gamma$ inhibits NMDA currents in Xenopus laevis oocytes. $\boldsymbol{A}$, Left, Representative traces of whole-cell NR1/2A currents recorded with the two-electrode voltage-clamp technique at $-80 \mathrm{mV}$ (in this and subsequent figures). NR1/2A currents were evoked by NMDA (100 $\mu \mathrm{M}$ ) and glycine (Gly; $10 \mu \mathrm{m}$ ) applied as indicated by arrows, in control cells (b), cells overexpressing $\operatorname{PLC} \gamma(\mathrm{a})$, or cells expressing the inactive mutant $\operatorname{PLC} \gamma_{\mathrm{Y783F}}(\mathrm{c})$, as described in Results. Right, Bars representing mean \pm SE percentage steady-state current after agonist application, normalized to the average of the control group. The means for the $\mathrm{PLC} \gamma$ group were significantly different ( ${ }^{*} p<0.01$, $t$ test). $\boldsymbol{B}$, Bars obtained similarly as in $\boldsymbol{A}$ but for NR1/2A or NR1/2B currents from control 0ocytes or 0ocytes preincubated for $1 \mathrm{~h}$ with $10 \mu \mathrm{m}$ wortmannin (Wtmn). The means were significantly different in all sets of experiments ( $p<0.001, t$ test).

tion of NMDA $(100 \mu \mathrm{M})$ and glycine $(10 \mu \mathrm{M})$. Overexpression of PLC $\gamma$, which catalyzes the hydrolysis of $\mathrm{PIP}_{2}$, significantly reduced NMDA currents compared with oocytes, in which PLC $\gamma$ was not overexpressed (Fig. $1 \mathrm{~A}, \mathrm{a}, \mathrm{b}$ ). As an additional control for this experiment, we used the mutant PLC $\gamma_{\mathrm{Y} 783 \mathrm{~F}}$, in which mutation of the critical tyrosine 783 to phenylalanine uncouples the $\mathrm{PIP}_{2}$-hydrolyzing activity of the enzyme (Kim et al., 1991). Expression of this inactive PLC $\gamma$ did not affect the full-size NMDA currents (Fig. 1A, c) (control oocytes, normalized current was $100 \pm 12 \%, n=15 ;+$ PLC $\gamma$ oocytes, $63.9 \pm 6.3 \%, n=14$ $+\mathrm{PLC} \gamma_{\mathrm{Y} 783 \mathrm{~F}}$ oocytes, $\left.99 \pm 1 \%, n=11\right)$. These results show that tonic increase of PLC $\gamma$ activity inhibits NMDA currents. To test whether reduced $\mathrm{PIP}_{2}$ levels could account for the inhibition of NMDA currents, we used the pharmacological inhibitor wortmannin. Application of this substance at micromolar concentrations interferes with the biosynthetic cycle of $\mathrm{PIP}_{2}$ by blocking a type III phosphatidylinositol-4 (PI-4) kinase isoform (Nakanishi et al., 1995; Balla, 1998). Pretreatment of oocytes for $1 \mathrm{~h}$ with 10 $\mu \mathrm{M}$ wortmannin mimicked the effect of PLC $\gamma$ overexpression, significantly reducing NMDA currents. We tested this effect for both NR1/2A and NR1/2B heteromers, with similar results (Fig. 1B) $(\mathrm{NR} 1 / 2 \mathrm{~A}$, normalized control current was $100 \pm 5.8 \%, n=$ 10 cells; wortmannin treated, $45.7 \pm 6.7 \%, n=10$ cells; NR $1 / 2 \mathrm{~B}$, normalized control current was $100 \pm 8.8 \%, n=9$ cells; wortmannin treated, $22.7 \pm 2.7 \%, n=7$ cells). Another pharmacological $\mathrm{PIP}_{2}$ probe is neomycin, an antibiotic substance that sequesters $\mathrm{PIP}_{2}$ through electrostatic interactions attributable to its polycationic nature (Krauter et al., 2001; Ding et al., 2004). We injected neomycin into Xenopus laevis oocytes during recording (Mullner et al., 2000) of NMDA currents by two-electrode voltage clamp. Injection of neomycin to a final intracellular concentration of $5 \mu \mathrm{g} / \mu \mathrm{l}$ suppressed the current of NR1/2A heteromers (supplemental Fig. 1, available at www.jneurosci.org as supplemental material) (normalized current after injection of vehicle
A
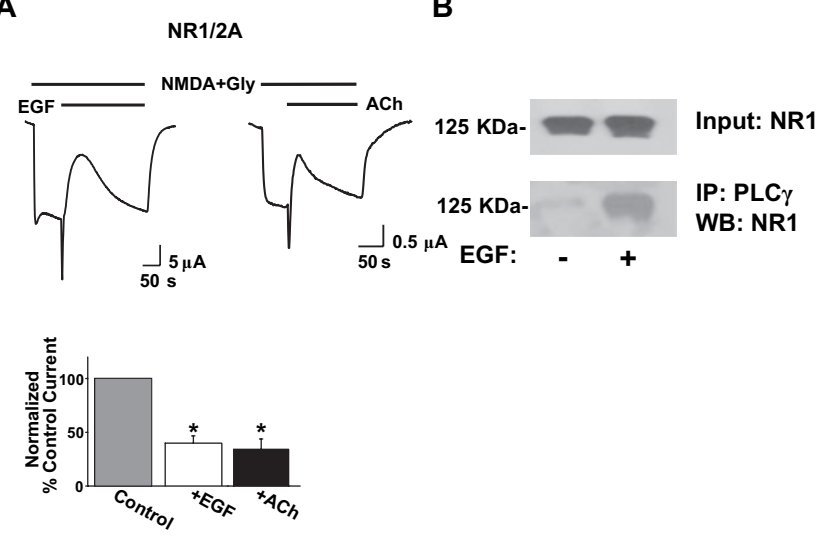

Figure 2. Stimulation of hormonal receptors that activate PLC transiently inhibits NMDA currents. $A$, Representative traces of the effect to the NR1/2A current of $100 \mathrm{ng} / \mathrm{ml} \mathrm{EGF} \mathrm{or} 5 \mu \mathrm{m}$ $A C h$ applied as shown. Bars represent mean \pm SE percentage current of current before (control current, taken as always $100 \%$ before EGF or ACh application in this and subsequent figures when comparison with inhibited states is made) or of maximally inhibited current after EGF or $A C h$ application. Both means representing inhibited current were significantly different from control ( ${ }^{*} p<0.001, t$ test). $B$, Xenopus 0ocytes expressing NR1/2A subunits and EGFR were stimulated with EGF $(100 \mathrm{ng} / \mathrm{ml})$ as indicated, and membrane preparations were obtained as described in Materials and Methods. Top, Western immunoblot (WB) of a sample of the membrane preparations with an antibody against NR1. The rest of the same membrane preparations were subjected to immunoprecipitation (IP) using an antibody against PLC $\gamma$ (see Materials and Methods). Bottom, NR1 Western blotting of oocyte membrane immunoprecipitates pulled down with PLC $\gamma$ antibodies. Blots are representative of two independent experiments with similar results.

solution or neomycin compared with the current before injection was $106.71 \pm 4.34 \%, n=12$ cells and $64.71 \pm 4.81 \%, n=17$ cells, respectively). These findings altogether are consistent with the interpretation that removal of $\mathrm{PIP}_{2}$ inhibits partially NMDAR currents.

PLC-catalyzed $\mathrm{PIP}_{2}$ hydrolysis is enhanced by hormonal receptor stimulation. For example, stimulation of the EGFR, a receptor tyrosine kinase of the ErbB family, can trigger $\mathrm{PIP}_{2}$ hydrolysis via PLC $\gamma$ through a well studied tyrosine phosphorylation cascade (Rhee and Bae, 1997). During application of EGF in oocytes expressing EGFR and NR1/2A subunits, the endogenous $\mathrm{Ca}^{2+}$-dependent chloride current was activated transiently (Weber, 1999), serving as a positive indicator for the EGF-induced hydrolysis of $\mathrm{PIP}_{2}$. After the chloride current, a robust transient inhibition of the NMDA current was evident (Fig. $2 A$, left trace) (the EGF-inhibited current was $40 \pm 7 \%$ of the current before the EGF application, $n=30$ cells). To test whether this effect is unique for the EGFR or whether alternative pathways causing $\mathrm{PIP}_{2}$ hydrolysis can similarly affect NMDARs, we used the muscarinic $\mathrm{M}_{1}$ acetylcholine (ACh) receptor, a G-protein-coupled receptor that couples to PLC $\beta$ (Rhee and Bae, 1997). As with EGF, application of $\mathrm{ACh}$ elicited the $\mathrm{Ca}^{2+}$-dependent chloride current and a transient inhibition of the NMDA current (Fig. $2 \mathrm{~A}$, right trace) (the ACh-inhibited current was $35 \pm 10 \%$ of the current before ACh application, $n=30$ cells). This effect was also seen with NR1/2B currents as well (data not shown). These results suggest that hormone-induced $\mathrm{PIP}_{2}$ hydrolysis leads to NMDA current inhibition.

If $\mathrm{PIP}_{2}$ regulates NMDARs directly, then the $\mathrm{PIP}_{2}$ signaling machinery may be expected to associate with NMDAR subunits. We tested whether there is an interaction between NMDARs and PLC $\gamma$ in our system using coimmunoprecipitation. We used an antibody against PLC $\gamma$ to pull down PLC $\gamma$ immunocomplexes 
A

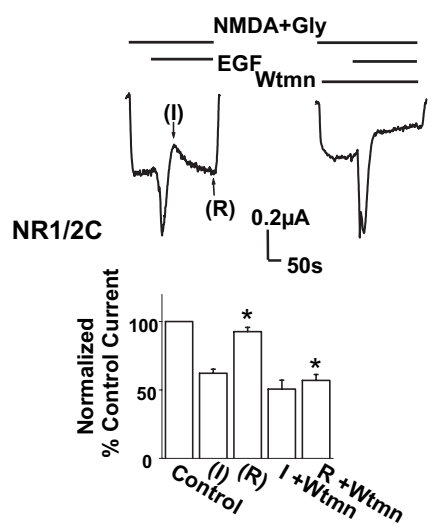

B

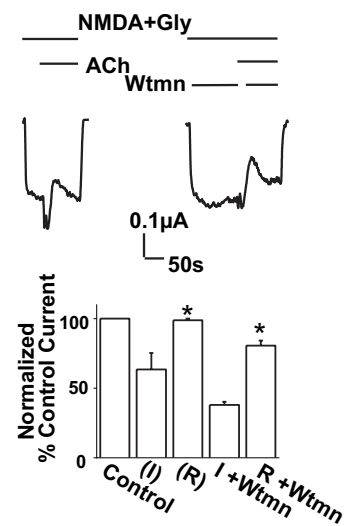

Figure 3. Wortmannin blocks the recovery of NMDA currents in response to PLC-coupled receptor stimulation. $\boldsymbol{A}, \boldsymbol{B}$, Left traces, Effect to the NR1/2C current of $100 \mathrm{ng} / \mathrm{mlEGF}$ or $5 \mu \mathrm{m} A C h$ applied as indicated. Right traces, In addition to EGF or ACh, wortmannin (Wtmn; $20-40 \mu \mathrm{m}$ ) was perfused to the 0ocyte (different 0ocytes from the ones used in experiments without wortmannin) as indicated. Bars represent mean \pm SE percentage current of current before (control current) or of maximally inhibited current after EGF or ACh application (I) or of recovered current (R) from cells with or without wortmannin (I, R + wortmannin). * $p<0.001$, the mean maximally recovered currents in cells perfused with wortmannin were significantly different than control cells (for both EGF and Ach; $t$ test). The arrows indicate where the I and $R$ measurements were made. Gly, Glycine.

from oocytes expressing NR1/2A subunits. Interestingly, in the same immunocomplexes, we detected the presence of the NR1 subunit of NMDARs, particularly when the cells were treated with EGF (Fig. $2 B$, bottom). This enrichment is consistent with the fact that EGF promotes the translocation of PLC $\gamma$ from the cytosol to the plasma membrane (Rhee and Bae, 1997). Moreover, this result shows that NMDARs and PLC $\gamma$ can interact.

Because the hydrolysis of $\mathrm{PIP}_{2}$ can trigger the release of $\mathrm{Ca}^{2+}$ from intracellular stores, which can have many biological effects including PKC activation, we tested the effects of EGF and ACh on NR1/2C currents. These channels, unlike the NR1/2A subunit heteromers (Krupp et al., 1996; Liao et al., 2001), are insensitive to regulation by any potential activation of $\mathrm{PKC}$ and do not show $\mathrm{Ca}^{2+}$-dependent inactivation. As with NR1/2A, application of EGF produced a $\mathrm{Ca}^{2+}$-dependent chloride current that was followed by inhibition of the NMDA current and recovery (Fig. $3 A$, left trace). Interestingly, real-time application of wortmannin prevented current recovery, resulting in significantly more inhibited current levels compared with control (Fig. $3 A$, right trace) (control cells: EGF-inhibited current was $62 \pm 3 \%$ of the current before EGF application, recovered current was $92.7 \pm 3 \%, n=4$ cells; cells with acute wortmannin application: inhibited current was $50.7 \pm 6.4 \%$ of the current before EGF application, recovered current was $57 \pm 4.3 \%, n=4$ cells). This result argues that the EGF-induced inhibition of the NMDA current is not attributable to $\mathrm{PKC}$ activation and does not reflect a $\mathrm{Ca}^{2+}$-dependent inactivation process. In contrast, these results are consistent with the notion that $\mathrm{PIP}_{2}$ hydrolysis causes the inhibition of the NMDA current and that $\mathrm{PIP}_{2}$ resynthesis accounts for the recovery. Indeed, $\mathrm{Ca}^{2+}$-mobilizing hormones may stimulate the synthesis of $\mathrm{PIP}_{2}$ in addition to its breakdown (Xu et al., 2003). Consistent with this interpretation, the EGFR can interact with some PI kinases and stimulate their activity (Cochet et al., 1991). A similar response was seen with $\mathrm{ACh}$ stimulation, i.e., inhibition of NR1/2C currents followed by recovery (Fig. 3B, left trace), and wortmannin enhanced the ACh-dependent inhibition and sig-
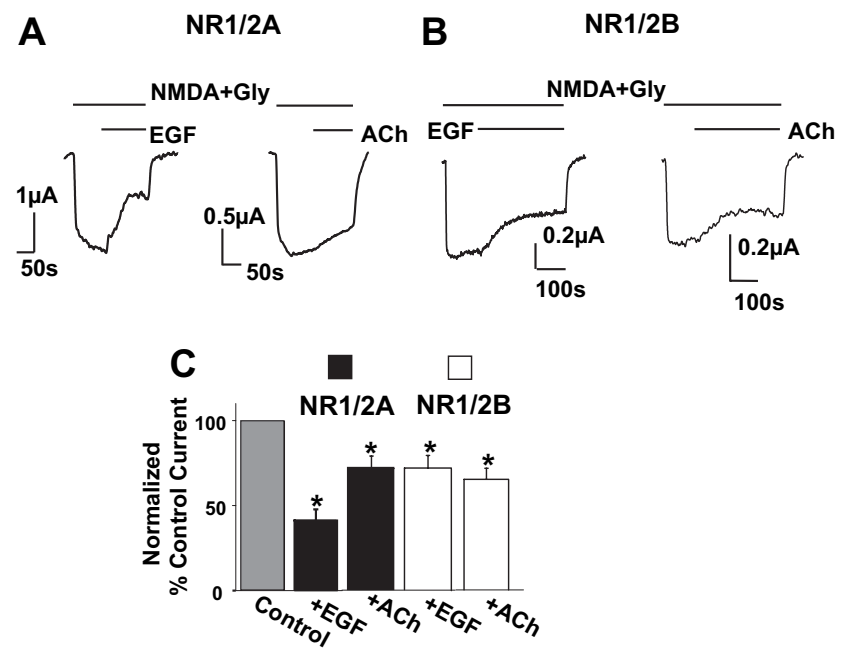

Figure 4. Intracellular $\mathrm{Ca}^{2+}$ store depletion does not prevent NMDA current inhibition in response to PLC-coupled receptor stimulation. $\boldsymbol{A}, \boldsymbol{B}$, Traces represent NMDA currents recorded from oocytes expressing NR1/2A $(\boldsymbol{A})$ or NR1/2B $(\boldsymbol{B})$ subunits on which EGF or ACh were administered as indicated. Thapsigargin (1-5 $\mu \mathrm{m}$ ) was used to pretreat the 00 cytes for $30-60 \mathrm{~min}$ before experiments. C, Bars represent mean \pm SE percentage current of current before (control current) or of maximally inhibited current after EGF $(100 \mathrm{ng} / \mathrm{ml})$ or ACh $(5 \mu \mathrm{m})$ application. All sets of means were significantly different $\left({ }^{*} p<0.001, t\right.$ test). Gly, Glycine.

nificantly attenuated recovery, although to a lesser extent than for EGF (Fig. 3B, right trace) (control cells: ACh-inhibited current was $63.5 \pm 11 \%$ of the current before ACh application, recovered current was $98.7 \pm 1.2 \%, n=4$ cells; cells with acute wortmannin application: inhibited current was $37.9 \pm 2.4 \%$ of the current before ACh application, recovered current was $80.5 \pm 3.7 \%, n=$ 4 cells). We observed a similar pattern of regulation with NR1/2A currents as well (data not shown). These results suggest that hormone-induced $\mathrm{PIP}_{2}$ hydrolysis and resynthesis may underlie the effects on NMDA currents.

To further test for any potential role of $\mathrm{Ca}^{2+}$ in these experiments, we used thapsigargin, a drug that depletes $\mathrm{Ca}^{2+}$ from intracellular stores. Thus, during hormonal stimulation of thapsigargin-pretreated oocytes, there should be no available $\mathrm{Ca}^{2+}$ to signal via $\mathrm{IP}_{3}$ receptors as a result of $\mathrm{PIP}_{2}$ hydrolysis. As expected, 30-60 min preincubation of oocytes with $5 \mu \mathrm{M}$ thapsigargin eliminated $\mathrm{Ca}^{2+}$-activated chloride currents (Fig. 4, traces; compare with Figs. 2, 3), yet application of EGF (Fig. 4A, left trace) or ACh (Fig. $4 A$, right trace) induced a sizeable steadystate inhibition of NR1/2A currents (the ACh-inhibited current was $74.3 \pm 8 \%, n=5$ cells; the EGF-inhibited current was $41.8 \pm$ $5.9 \%, n=5$ cells). NR1/2B currents, whose $\mathrm{Ca}^{2+}$-dependent inactivation is insignificant (Krupp et al., 1996), were also robustly inhibited by either EGF (Fig. 4B, left trace) or ACh (Fig. $4 B$, right trace) in thapsigargin-treated oocytes (the EGFinhibited current was 71.4 $\pm 7.3 \%$ of current before EGF application, $n=8$ cells; the ACh-inhibited current was $70 \pm 6 \%$ of current before ACh application, $n=8$ cells). These results strongly suggest that the inhibitory effect of PLC-coupled receptors on NMDA currents is not attributable to an action of $\mathrm{Ca}^{2+}$. Conversely, these data rather corroborate the idea that $\mathrm{PIP}_{2}$ breakdown, as caused by the two independent pathways tested, downregulates NMDAR activity. Interestingly, thapsigargin treatment abolished the transient nature of the inhibitory response to EGF or ACh. The recovery phase that we showed to be dependent on wortmannin treatment (Fig. 3) was also greatly dependent on intracellular $\mathrm{Ca}^{2+}$. This is consistent with recent 


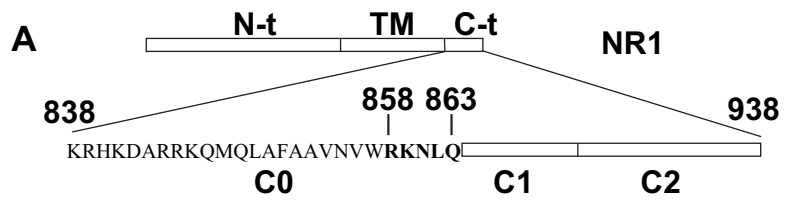

B

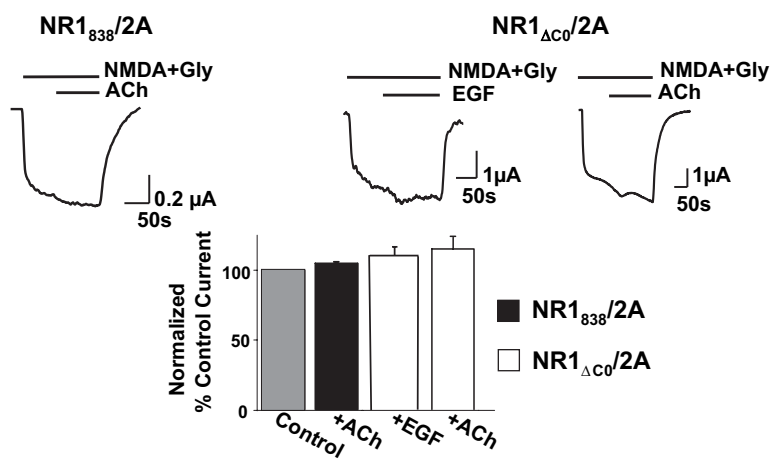

Figure 5. The $\mathrm{C} 0$ domain of the NR1 subunit is required for the inhibition of NR1/2A currents. $\boldsymbol{A}$, The $C$ terminus of NR1 (NR1-1b). Shown in bold are the $\alpha$-actinin-binding residues within CO. $\boldsymbol{B}$, Traces represent recordings of NMDA currents from oocytes expressing the NR1 deletion mutant subunits indicated (see Results) with wild-type NR2A subunit, in which EGF (1 ng/ml) or ACh $(5 \mu \mathrm{M})$ were applied as indicated. In NR1 ${ }_{838}$ and NR1 ${ }_{\Delta C}$, the $C$ terminus of NR1 or only its $\mathrm{C} 0$ domain have been deleted, respectively. Bars represent mean $\pm \mathrm{SE}$ percentage current of current before (control current) or of current after EGF or ACh application. The means were not significantly different ( $t$ test). Gly, Glycine; TM, transmembrane domain.

work showing that intracellular $\mathrm{Ca}^{2+}$ release after PLC activation by some agonists stimulates a PI-4 kinase isoform to resynthesize $\mathrm{PIP}_{2}$ almost concurrently with PLC activation (Gamper et al., 2004; Hughes et al., 2007; Pian et al., 2007), which could account for NMDA current recovery according to our hypothesis.

$\mathrm{PIP}_{2}$ may directly bind to the NR1 subunit (McLaughlin and Murray, 2005), yet we found that application of $\mathrm{PIP}_{2}$ or $\mathrm{PIP}_{2}$ antibody did not affect NMDAR activity in stable excised insideout patches (data not shown). These results suggest that a cytoplasmic factor may be involved in mediating the effects of $\mathrm{PIP}_{2}$ hydrolysis.

We next sought to identify the sites on NMDARs responsible for "sensing" $\mathrm{PIP}_{2}$ hydrolysis. The $\mathrm{C}$ terminus of NR1 can be divided into three domains, $\mathrm{C} 0, \mathrm{C} 1$, and $\mathrm{C} 2$ (Fig. $5 A$ ), in which the $\mathrm{C} 1$ and $\mathrm{C} 2$ cassettes are targets of alternative splicing (Zukin and Bennett, 1995). Interestingly, the C terminus of NR1 is the site of many crucial protein-protein interactions for NMDARs, such as with calmodulin (Ehlers et al., 1996), $\alpha$-actinin (Wyszynski et al., 1997; Krupp et al., 1999), CaMKII (Leonard et al., 2002), tubulin (van Rossum et al., 1999), spectrin (Wechsler and Teichberg, 1998), etc. Deletion of the entire C terminus of NR1 downstream of residue $838\left(\mathrm{NR}_{838}\right)$ abolished any effect of $\mathrm{ACh}$ on NR1/2A currents, indicating that a site somewhere along the deleted intracellular domain of the NR1 subunit is critical to transduce the effect of $\mathrm{PIP}_{2}$ hydrolysis (Fig. $5 \mathrm{~B}$, left trace) $\left(\mathrm{NR}_{838} / 2 \mathrm{~A}\right.$ current after Ach application, $105 \pm 1 \%$ of the current before, $n=10$ cells). We tested whether the region enabling $\mathrm{PIP}_{2}$ regulation could be narrowed down to the $\mathrm{C} 0$ domain by deleting this domain only (residues $838-863)$ of NR1 $\left(N R 1_{\Delta \mathrm{C} 0}\right)$. We found that both the EGF-induced (Fig. $5 B$, middle trace) and the AChinduced (Fig. 5B, right trace) inhibitions were absent in $\mathrm{NR} 1_{\Delta C 0} / 2 \mathrm{~A}$ heteromers, suggesting that $\mathrm{C} 0$ is a necessary element for the regulation of NR1/2A currents by PLC-coupled receptors (ACh, current after ACh application was $115 \pm 8 \%$ of the current
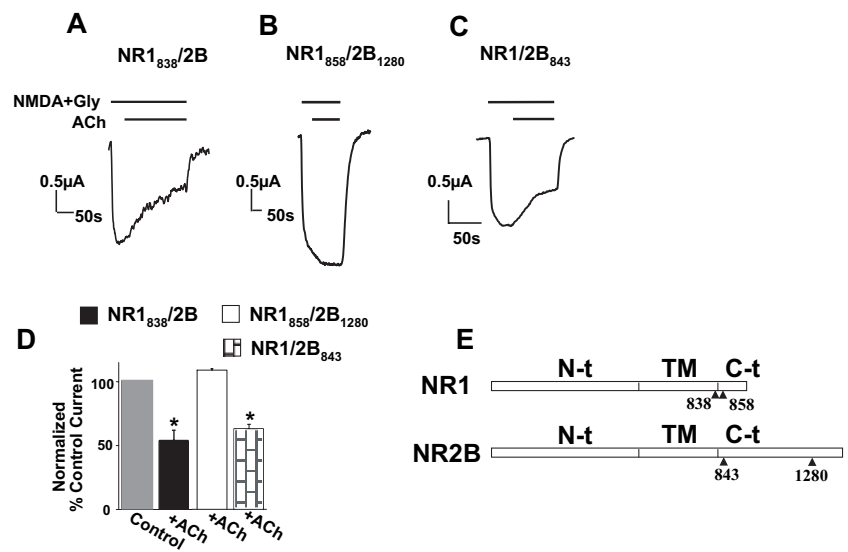

Figure 6. $\alpha$-Actinin-binding sites within the CO domain of NR1 and the distal $\alpha$-actininbinding region of the $C$ terminus of NR2B are required for inhibition of NR1/2B currents. $A-C$, Traces represent recordings of NMDA currents from thapsigargin-treated oocytes expressing wild-type NR1 or NR1 deletion mutants, together with wild-type NR2B or an NR2B mutant as indicated. EGF (100 ng/ml) or ACh (5 $\mu \mathrm{m})$ were applied as indicated. The constructs have been named after the last residue expressed in the mutant subunit (see Results). D, Bars represent mean \pm SE percentage current of current before (control current) or of steady-state current after EGF or ACh application. The means were significantly different only for NR1 or NR2B subunit combinations that contained an $\alpha$-actinin-binding site ( $p<0.01, t$ test). D, Schematic of NR1 and NR2B subunits with sites of mutants used. $\alpha$-Actinin binds residues $858-863$ of NR1 (see also Fig. 5) and the distal ( terminus of NR2B. Gly, Glycine; TM, transmembrane domain.

before, $n=10$ cells; EGF, current after EGF application was $112 \pm 6 \%$ of the current before, $n=10$ cells). Typically, $\mathrm{NR} 1_{838} / 2 \mathrm{~A}$ currents were markedly smaller than their wild-type counterparts (see representative trace in Fig. 5B, left). We have shown that $\mathrm{NR} 1_{\Delta \mathrm{C} 0} / 2 \mathrm{~A}$ currents are larger than wild type (Scott et al., 2004), which is attributable to inhibition of C0-dependent channel internalization.

When we used NR2B instead of NR2A as the partner subunit of $\mathrm{NR}_{838}$, the ACh-induced inhibition took place normally (Fig. $6 A, D)$ (the ACh-inhibited $N R 1_{838} / 2 \mathrm{~B}$ current was $54 \pm 8 \%$ of the current before ACh application, $n=4)$. Of the known binding partners of NMDARs, $\alpha$-actinin has been shown to bind to NR1 (residues 858-863 of $\mathrm{C} 0$ ) and the NR2B distal C terminus but not the corresponding NR2A region (Wyszynski et al., 1997) (Figs. $5 A, 6 E$ ). It is possible that $\mathrm{PIP}_{2}$ hydrolysis effects could be mediated through $\alpha$-actinin, in that inhibition was not possible for the $\mathrm{NR} 1_{838} / 2 \mathrm{~A}$ and $\mathrm{NR} 1_{\Delta \mathrm{C} 0} / 2 \mathrm{~A}$ heteromers that do not interact with $\alpha$-actinin, whereas $\mathrm{NR}_{838} / 2 \mathrm{~B}$ heteromers, which can interact with $\alpha$-actinin via NR2B, would "rescue" the inhibitory phenotype. We next removed the $\alpha$-actinin-binding site of NR2B by deleting only the distal $C$ terminus of this subunit downstream of residue $1280\left(\mathrm{NR}_{2} \mathrm{~B}_{1280}\right)$ (Fig. 6B,E). Indeed, expression of $\mathrm{NR} 2 \mathrm{~B}_{1280}$ together with $\mathrm{NR} 1_{858}$, which contained an additional 20 amino acids compared with $\mathrm{NR}_{838}$ but still eliminated the $\alpha$-actinin-binding site, was not inhibited by ACh (Fig. 6B,D) $\left(\mathrm{NR} 1_{858} / 2 \mathrm{~B}_{1280}\right.$ current after ACh application was $109 \pm 1 \%$ of previous current, $n=4)$. $\mathrm{NR}_{858}$ when expressed with NR2A also failed to show an ACh-induced inhibitory phenotype (data not shown). As expected, expression of the full-length NR1, bearing an intact $\alpha$-actinin-binding site, with a mutant $\mathrm{NR}_{2} \mathrm{~B}_{843}$, in which the entire $\mathrm{C}$ terminus of this subunit had been deleted, did not prevent the ACh-induced inhibition of these heteromers (Fig. 6C,D) $\left(\mathrm{NR} 1 / 2 \mathrm{~B}_{843}\right.$, ACh-inhibited current was $63.4 \pm 3.4 \%$ of current before ACh application, $n=4$ ). Deletion of the $\mathrm{C}$ terminus of NR2A had no effect on the ACh-induced inhibition 
(data not shown). Finally, in addition to the chimeras, an NR1 single-point mutant R859Q within the minimal $\alpha$-actininbinding segment (858-863) significantly attenuated the effect of EGF on NR1/2A heteromers (supplemental Fig. 2, available at www.jneurosci.org as supplemental material) (NR1/2A current after EGF application reached an average value of $37.2 \pm 2.2 \%$ of the current before EGF application, whereas $\mathrm{NR} 1_{\mathrm{R} 859 \mathrm{Q}} / 2 \mathrm{~A}$ current after EGF application was $67 \pm 5 \% ; n=6$ for both groups). This region has been shown to control the binding of NR1 to $\alpha$-actinin, whose disruption leads to $\mathrm{Ca}^{2+}$-dependent inactivation in hippocampal neurons (Krupp et al., 1999). These data strongly point to $\alpha$-actinin as a mediator of the effect of $\mathrm{PIP}_{2}$ breakdown on NMDAR currents.

We tested whether $\mathrm{PIP}_{2}$ levels affected the interaction of NMDARs with $\alpha$-actinin using coimmunoprecipitation. We pulled down immunocomplexes from oocyte membrane preparations using an antibody against $\alpha$-actinin. Interestingly, EGF dramatically increased the amount of NR1 in the immunoprecipitates (supplemental Fig. 3, bottom left gel, available at www. jneurosci.org as supplemental material) without affecting the total NR1 protein (supplemental Fig. 3, top left gel, available at www.jneurosci.org as supplemental material). Wortmannin preincubation acted in a manner similar to EGF (supplemental Fig. 3 , right gels, available at www.jneurosci.org as supplemental material). These results show that treatments that cause a decrease in $\mathrm{PIP}_{2}$ levels inhibit NMDA currents, increasing $\alpha$-actinin-NR1 immunocomplexes.

The binding of $\alpha$-actinin to NMDARs favors the channel open state, keeping intracellular $\mathrm{C}$ termini apart by tethering them to the actin cytoskeleton (Ehlers et al., 1996; Zhang et al., 1998; Krupp et al., 1999). Because $\alpha$-actinin also binds $\mathrm{PIP}_{2}$ (Fukami et al., 1992; Fukami et al., 1996), it is possible that $\mathrm{PIP}_{2}$ binding maintains this state by tethering $\alpha$-actinin to the plasma membrane. PIP $_{2}$ breakdown or depletion would therefore allow channel closure. To test this model, we mutated the two basic residues, R172 and K184, which mainly carry the interaction with the negatively charged phospholipid (Fukami et al., 1996). Expression of two $\alpha$-actinin 2 mutants, one bearing the single K184Q and the other the double-mutation R172Q-K184Q, caused a progressive inhibitory effect on NMDA currents compared with control oocytes or oocytes overexpressing wild-type $\alpha$-actinin (Fig. 7, top left bars) (control oocytes: normalized NMDA current was $100 \pm$ 5.6\%, $n=56 ; \alpha$-actinin-overexpressing oocytes: $73.05 \pm 4.7 \%$ of control group, $n=60 ; \alpha$-actinin K184Q-expressing oocytes: NMDA current was $32.5 \pm 2.7 \%$ of control, $n=50 ; \alpha$-actinin R172Q-K184Q-expressing oocytes: NMDA current was $5.2 \pm$ $0.1 \%$ of control, $n=7$ ). This result is consistent with $\alpha$-actinin mutants acting in a dominant-negative manner, binding NMDARs and uncoupling them from the inner leaflet of the membrane in which $\mathrm{PIP}_{2}$ resides. Furthermore, the single K184Q mutant occluded the effect of EGF on NMDA currents (Fig. 7, bottom left trace, compare with top right), (EGF-inhibited current in control cells: $65.03 \pm 5 \%$ of the current before EGF application, $n=13$; EGF-inhibited current in $\alpha$-actininoverexpressing cells: $77.5 \pm 7.2 \%$ of the previous current, $n=16$; current after EGF application in K184Q-expressing cells: $111.4 \pm$ $10 \%$ of the previous current, $n=13$ ). Thus, dominant-negative $\alpha$-actinin presumably occluded the effect of $\mathrm{PIP}_{2}$ hydrolysis on the NMDA current. This result is consistent with a "tonic" inhibition of the NMDA current by $\mathrm{PIP}_{2}$-stripped $\alpha$-actinin.

We next asked whether the mechanism of $\mathrm{PIP}_{2}$ regulation of NMDARs via $\alpha$-actinin emerging from the data above can affect the physiology of native NMDA currents in primary neuronal
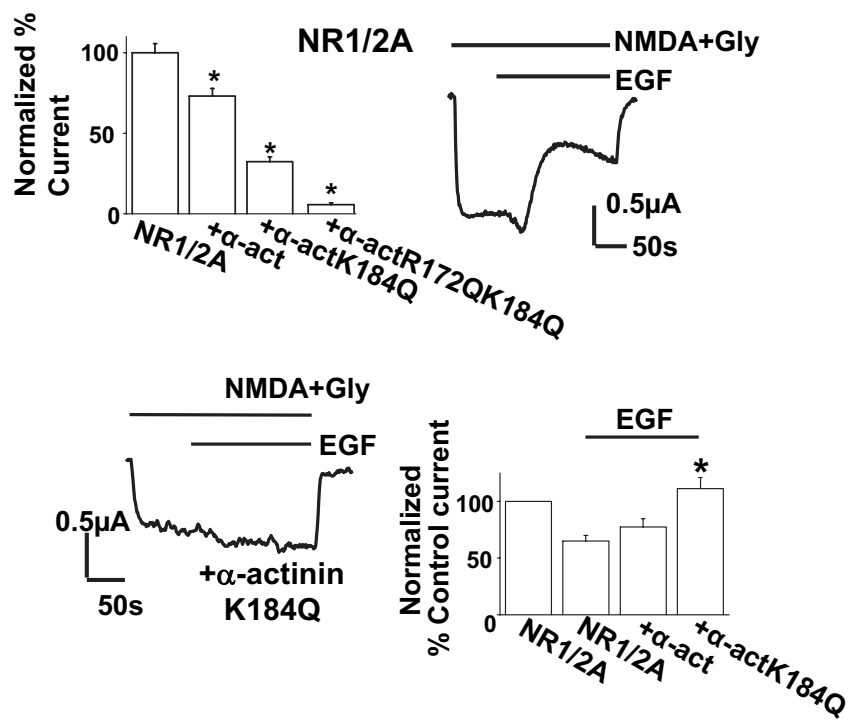

Figure 7. Mutation of the $\mathrm{PIP}_{2}$-binding residues of $\alpha$-actinin affects NMDA currents in 00 cytes. Top left, Bars representing mean \pm SE percentage steady-state normalized NMDA current recorded from oocytes expressing NR1/2A together with endogenous $\alpha$-actinin (control), overexpressed wild-type $\alpha$-actinin 2, single-point mutant $\alpha$-actinin 2 K184Q, or double-point mutant $\alpha$-actinin 2 R1720-K184Q. The means were significantly different from control ( $p<$ 0.001 for all comparisons, $t$ tests). Top right, Representative NMDA current trace of a control oocyte expressing NR1/2A in response to EGF (1 ng/ml) applied as indicated. Bottom left, Representative NMDA current trace of an oocyte expressing NR1/2A and single-point mutant $\alpha$-actinin $2 \mathrm{~K} 184 \mathrm{Q}$ in response to $1 \mathrm{ng} / \mathrm{ml}$ EGF. Bottom right, Bars represent mean \pm SE percentage current of current before (control current) or of steady-state current after EGF application from oocytes expressing NR1/2A, and NR1/2A together with wild-type $\alpha$-actinin 2 or single-point mutant $\alpha$-actinin $2 \mathrm{~K} 1840 .{ }^{*} p<0.001$, statistically significant difference between the NR1/2A group and the K1840 group ( $t$ test).

cultures. For this purpose, $\alpha$-actinin 2 and its R172Q-K184Q mutant were $\mathrm{N}$-terminally tagged with EGFP, transfected into 17-24 d in vitro cultured hippocampal neurons, and the fluorescently identified transfected neurons were subjected to whole-cell patch-clamp recordings. Under these conditions, expression of $\alpha$-actinin R172Q-K184Q caused a significant reduction on both the peak and the steady-state NMDA current compared with expression of wild-type $\alpha$-actinin (Fig. 8). As a control, EGFP was also transfected into hippocampal neurons (data not shown) [normalized peak NMDA current (in ratio with $\mathrm{K}^{+}$current; see Materials and Methods) for $\alpha$-actinin-EGFP, $100 \pm 2 \%$; $\alpha$-actinin-EGFP R172Q-K184Q: $85 \pm 2 \%$; normalized NMDA current $1 \mathrm{~s}$ after peak: $\alpha$-actinin-EGFP, $27 \pm 1.4 \%$ of peak; $\alpha$-actininEGFP R172Q-K184Q, $16.7 \pm 1 \%$ ]. Moreover, the kinetics of inactivation appeared significantly accelerated by the mutant $\alpha$-actinin (tau inactivation for $\alpha$-actinin-EGFP: $463.1 \pm 19.8 \mathrm{~ms}$, $n=28 ; \alpha$-actinin R172Q-K184Q-EGFP: $383.6 \pm 11.6, n=25$ neurons). Thus, neuronal NMDA currents are significantly decreased and reach their fully inactivated state faster in the presence of $\alpha$-actinin R172Q-K184Q, which is consistent with the tonic inhibition by this mutant, in agreement with our oocyte expression results. Interestingly, the effect was more pronounced toward the more sustained phase of the current (Fig. 8C). Conversely, transfection of the PH domain of PLC $\delta$ (also tagged with EGFP), which sequesters PIP $_{2}$ (Stauffer et al., 1998; Raucher et al., 2000), also reduced the peak and the steady-state NMDA current and accelerated inactivation kinetics compared with expression of its inactive $\left(\mathrm{PH}^{*}\right)$ R40L mutant (van der Wal et al., 2001) (supplemental Fig. 4, available at www.jneurosci.org as supplemental material) (normalized peak NMDA current/K ${ }^{+}$current: 

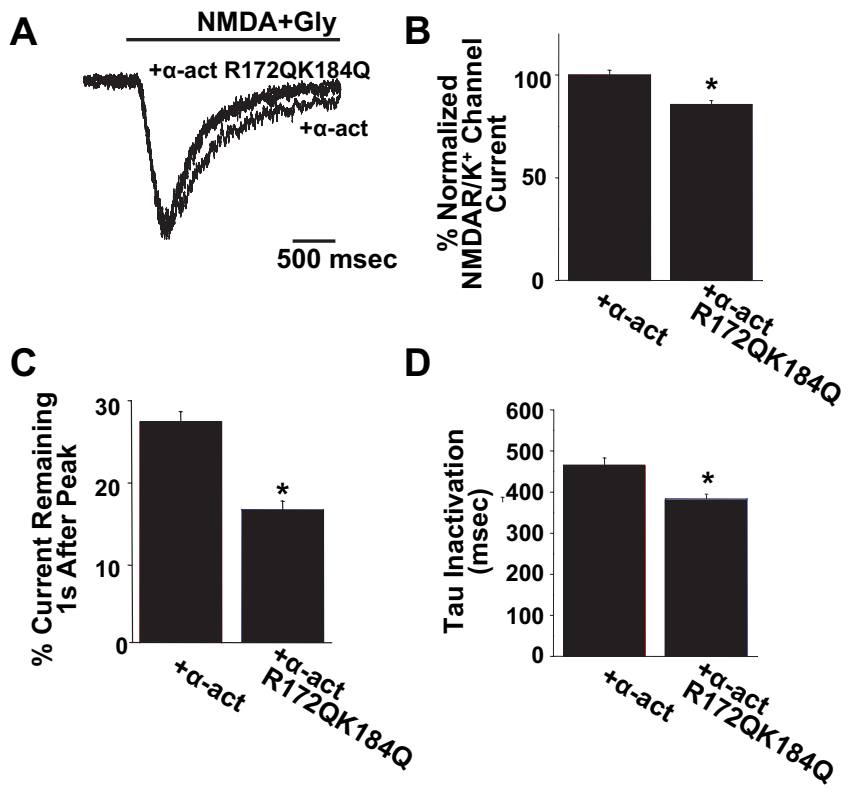

Figure 8. Disruption of the $\alpha$-actinin-PIP ${ }_{2}$ interaction affects NMDA currents in hippocampal neurons. $A$, Overlaid normalized representative NMDA- glycine-evoked current traces from neurons clamped at $-60 \mathrm{mV}$ expressing $\alpha$-actinin-EGFP (red) or the $\alpha$-actinin-EGFP R1720K184Q mutant (blue). For $\alpha$-actinin-EGFP and $\alpha$-actinin-EGFP R172Q-K184Q expressing neurons compared are mean \pm SE. $\boldsymbol{B}$, Percentage normalized peak NMDAR/K ${ }^{+}$channel current ratios obtained as described in Materials and Methods. $C$, Percentage of the peak NMDA current remaining $1 \mathrm{~s}$ after peak. $\boldsymbol{D}$, Time constants (tau) of inactivation of agonist-evoked NMDAR currents in neurons. All pairs of means were significantly different $\left({ }^{*} p<0.001, t\right.$ test). Gly, Glycine; $\alpha$-act, $\alpha$-actinin.

$\mathrm{PH}^{\star}-\mathrm{EGFP}, 100 \pm 2 \%$; PH-EGFP, $86 \pm 3 \%$; normalized NMDA current $1 \mathrm{~s}$ after peak: $\mathrm{PH}^{\star}-\mathrm{EGFP}, 35 \pm 1 \%$ of peak; PH-EGFP, $28 \pm 1.3 \%$; tau inactivation, $\mathrm{PH}^{*}-\mathrm{EGFP}, 603.2 \pm 15.8 \mathrm{~ms}, n=25$ neurons; PH-EGFP, $509 \pm 19.6, n=24$ neurons; data not shown for control EGFP neurons). Thus, as with oocytes, a more global disruption of $\mathrm{PIP}_{2}$ affected neuronal NMDA current parameters in a manner similar to interference with $\alpha$-actinin mutants.

\section{Discussion}

We propose a model (supplemental Fig. 5, available at www. jneurosci.org as supplemental material) in which $\alpha$-actinin interacts with $\mathrm{PIP}_{2}$ in the plasma membrane and promotes full opening of NMDARs. This model is consistent with all of our data. (1) Decreases in $\mathrm{PIP}_{2}$ caused by overexpression of PLC $\gamma$ or PLC $\delta$ $\mathrm{PH}$, micromolar wortmannin concentrations, neomycin injection, and EGF or ACh all inhibit NMDA currents, because $\alpha$-actinin would be unable to tether the cytosolic segment of the channel to the membrane to fully open it (supplemental Fig. $5 B$, available at www.jneurosci.org as supplemental material). (2) Overexpression of $\alpha$-actinin mutants unable to bind $\mathrm{PIP}_{2}$ decrease native and heterologously expressed NMDA currents by competing with endogenous $\alpha$-actinin binding in a dominantnegative manner (supplemental Fig. 5C, available at www. jneurosci.org as supplemental material). Moreover, the inactivation kinetics of native NMDA currents were significantly accelerated by coexpression in hippocampal neurons of $\alpha$-actinin mutants that were unable to bind $\mathrm{PIP}_{2}$. $\alpha$-Actinin mutant overexpression also occluded the ability of EGF to inhibit, as it presumably prevented the cytosolic segment to tether to the membrane and fully open (supplemental Fig. 5C, available at www.jneurosci.org as supplemental material). (3) $\alpha$-Actinin binding to the channel is necessary for the ACh or the EGF ef- fect to take place (supplemental Fig. 5D, available at www. jneurosci.org as supplemental material). The details of this model will clearly need to be tested by future work. For example, whether $\alpha$-actinin detachment from the membrane is required to produce the effects we describe remains an open question.

\section{The phosphoinositide modulation of ion channels includes NMDARs}

In oocytes, overexpression of PLC $\gamma$ to increase $\mathrm{PIP}_{2}$ hydrolysis (Kim et al., 1991), electrostatic sequestration of $\mathrm{PIP}_{2}$ by polycationic neomycin (Krauter et al., 2001; Ding et al., 2004), or wortmannin at micromolar concentrations to inhibit $\mathrm{PIP}_{2}$ synthesis (Willars et al., 1998) suppressed NMDA currents (Figs. 1, 3) (supplemental Fig. 1, available at www.jneurosci.org as supplemental material).

Stimulation of either EGFR or $\mathrm{M}_{1}$ receptor in oocytes caused an acute transient inhibition (Figs. $2 A, 3,4$ ). Both of these receptors cause the hydrolysis of $\mathrm{PIP}_{2}$ via distinct coupling to PLCs (Rhee and Bae, 1997). There is evidence that the EGFR binds some PI kinases (Cochet et al., 1991) and that $\mathrm{PIP}_{2}$ resynthesis can occur almost concurrently with its agonist-induced breakdown (Xu et al., 2003). This could explain the biphasic response, i.e., inhibition followed by recovery (Fig. 3), especially because application of wortmannin at micromolar concentrations to inhibit certain PI-4 kinases (Nakanishi et al., 1995) significantly retarded NR1/2C current recovery. These data altogether strongly support that NMDAR function requires $\mathrm{PIP}_{2}$.

Coimmunoprecipitation showed that PLC $\gamma$ and the NR1 subunit of NMDARs coexist in a complex (Fig. 2B). NR2A and NR2B bind to the SH2 (Src homology 2) domains of PLC $\gamma$ in vitro (Gurd and Bissoon, 1997). Proteomic analysis also detected PLC $\gamma$-NMDAR complexes in synaptic preparations (Husi et al., 2000). Our data are consistent with previous work and further point out a functional role for the interaction.

In oocytes unable to mobilize intracellular $\mathrm{Ca}^{2+}$ (Fig. 4), the response to EGF or ACh was steady-state inhibition. Such pattern of regulation in oocytes is strongly reminiscent of $\mathrm{PIP}_{2}$ dependent potassium channels, whose activity is inhibited by EGF or ACh (Kobrinsky et al., 2000). The inhibition of NMDA currents by EGF or ACh after thapsigargin pretreatment may rule out $\mathrm{Ca}^{2+}$ as the underlying cause. Thapsigargin always abolished calcium-activated chloride currents (Fig. 4 and other data not shown). This endogenous oocyte conductance is quite a sensitive indicator of intracellular $\mathrm{Ca}^{2+}$ release (Kobrinsky et al., 2000). Even for the experiments with intact stores (Figs. 2A, 3), it is unlikely that $\mathrm{Ca}^{2+}$ underlies inhibition, because NR1/2C heteromers (Fig. 3) do not have $\mathrm{Ca}^{2+}$-dependent inactivation (Krupp et al., 1996). PKC effects may not account for the effect either, because NR1/2C heteromers are insensitive to $\mathrm{PKC}$ regulation (Liao et al., 2001), and PKC inhibitor (staurosporine and bisindolylmaleimide) or phosphatase inhibitor application (okadaic acid) failed to affect ACh inhibition. PKC blockade was confirmed by measuring phorbol ester-induced inhibition of Kir2.3 currents in oocytes (data not shown) (Du et al., 2004).

It appears that the recovery from the inhibition is $\mathrm{Ca}^{2+} \mathrm{de}-$ pendent, in addition to wortmannin sensitive (compare Figs. $2 \mathrm{~A}$ and 3 with 4 ). One possibility is that capacitative $\mathrm{Ca}^{2+}$ release during thapsigargin pretreatment results in a more efficacious PLC activation and thus more dominant $\mathrm{PIP}_{2}$ hydrolysis over resynthesis. Another possibility is that, in intact cells, capacitative $\mathrm{Ca}^{2+}$ release stimulates a $\mathrm{Ca}^{2+}$-sensitive PI kinase activity (Gamper et al., 2004; Hughes et al., 2007; Pian et al., 2007). Interestingly, the $\mathrm{Ca}^{2+}$-binding protein NCS-1 (neuronal calcium 
sensor-1), which has a Xenopus homolog, can bind some PI-4 kinases and trigger $\mathrm{Ca}^{2+}$-dependent $\mathrm{PIP}_{2}$ resynthesis (Hendricks et al., 1999; Zhao et al., 2001; Koizumi et al., 2002).

Notably, wortmannin appears to have a lower potency in preventing recovery after ACh-dependent inhibition compared with EGF (Fig. 3). It is possible that the PI-4 kinase isoforms that are activated by the different ligands possess differential sensitivity to wortmannin.

\section{The effect of PLC-coupled receptors depends on $\alpha$-actinin-binding domains}

We identified C-terminal domains of NMDAR subunits controlling inhibition by PLC-coupled receptors. Deletion mutants displayed a practically "yes/no" phenotype, i.e., either preserved or prevented inhibition. Deletion of the NR1-C0 and the NR2B distal C terminus prevented inhibition (Figs. 5, 6). For NR1, the results pinpoint the $\alpha$-actinin-binding segment of C0 [residues 858-863 (Krupp et al., 1999)]. Residue R859 within that region attenuated the effect (supplemental Fig. 2, available at www. jneurosci.org as supplemental material). $\alpha$-Actinin binds NR1 and NR2B but not NR2A (Wyszynski et al., 1997), and deletion of NR2A C terminus did not significantly affect inhibition (data not shown). Thus, our functional results are in good agreement with the binding profile for $\alpha$-actinin. Other proteins such as postsynaptic density-95 (PSD-95) and spectrin bind NR2A (Kornau et al., 1995; Wechsler and Teichberg, 1998), yet we cannot completely rule out the existence of additional factors. Interestingly, tubulin, the monomer of microtubules, binds to NR1 and NR2B, but it has not been tested for its interaction, if any, with NR2A (van Rossum et al., 1999).

We also detected a change in NMDAR interaction with $\alpha$-actinin. Using coimmunoprecipitation, NR1 complexed with $\alpha$-actinin appeared significantly upregulated by EGF or wortmannin (supplemental Fig. 3, available at www.jneurosci.org as supplemental material). Because this apparent upregulation of $\alpha$-actinin-NR1 complexes occurs under conditions that reduce NMDA currents (Figs. 1,4), it should not promote channel opening. Our model (supplemental Fig. 5, available at www. jneurosci.org as supplemental material) can account for this result, because it assumes that $\alpha$-actinin molecules under these conditions fail to tether the channel $\mathrm{C}$ termini to the plasma membrane and open the channel as a result of their lack of interaction with $\mathrm{PIP}_{2}$. Furthermore, mutation of the binding site of $\alpha$-actinin for PIP $_{2}$ (Fukami et al., 1992, 1996), greatly inhibited NMDA currents and occluded the effect of EGF (Fig. 7).

Our model was further supported by studies on mature hippocampal neurons, in which we expressed mutant $\alpha$-actinin and the $\mathrm{PIP}_{2}$-sequestering PLC $\delta$-PH domain (Stauffer et al., 1998; Raucher et al., 2000) and studied their effects on native NMDA currents. Expression of these proteins inhibited both the peak and accelerated the inactivation of NMDA currents, fully consistent with a role for $\alpha$-actinin/PIP 2 in supporting NMDAR activity. The more pronounced effect in the late phase of the current could have important implications for the late phase of EPSPs, an idea that remains to be tested. Finally, the acceleration of inactivation kinetics by mutant $\alpha$-actinin or PLC $\delta-\mathrm{PH}$ is not surprising given that the $\mathrm{Ca}^{2+}$-dependent inactivation of NMDARs is attributable to displacement of $\alpha$-actinin by $\mathrm{Ca}^{2+} /$ calmodulin (Ehlers et al., 1996; Zhang et al., 1998; Krupp et al., 1999). This result is consistent with our model and shows how two modes of regulation, i.e., $\mathrm{Ca}^{2+}$-dependent inactivation and $\mathrm{PIP}_{2}$ regulation, can both converge on $\alpha$-actinin to affect NMDAR gating. Interestingly, these two modes of regulation of NMDA currents overlap in controlling kinetics, yet they are additive in controlling current amplitude. Notably, the effect of mutant $\alpha$-actinin on the inactivated NMDA current was somewhat more pronounced than that of PLC $\delta$-PH (Fig. 8) (supplemental Fig. 4, available at www.jneurosci.org as supplemental material). Thus, of the total cellular $\mathrm{PIP}_{2}$, an $\alpha$-actinin-controlled "pool" may specifically regulate NMDARs in the vicinity of these channels. This idea should be further tested.

In the absence of $\mathrm{PIP}_{2}, \alpha$-actinin forms dimers (Young and Gautel, 2000). We speculate that $\mathrm{PIP}_{2}$-stripped $\alpha$-actinin in a bulkier dimeric form may "jam" ion flow through NMDARs. The EGF- and wortmannin-upregulated $\alpha$-actinin-NR1 immunocomplexes may be adopting this state (supplemental Fig. 3, available at www.jneurosci.org as supplemental material). Such a scenario could also explain why overexpression of wild-type $\alpha$-actinin moderately inhibited NMDA currents (Fig. 7). According to this idea, a tetrameric channel could have its ion flow hindered even with just two subunit monomers interacting with $\alpha$-actinin. This was supported in our experiments when fulllength NR1 or NR2B with a mutant partner subunit was sufficient to sustain inhibition (Fig. 6A,D).

\section{Implications of the effect of PLC-coupled receptors on glutamatergic physiology and disease}

The EGFR belongs to the ErbB family of receptors. EGFRs are abundant in developing and mature neurons (Futamura et al., 2003). The most abundant ligand for CNS ErbB receptors is neuregulin (Buonanno and Fischbach, 2001). Intriguingly, ErbB-2 and ErbB-4 receptors accumulate in dendritic processes (Gerecke et al., 2001). NMDA and ErbB receptors accumulate at synaptic puncta and PSDs (Garcia et al., 2000), in which $\alpha$-actinin is also present (Wyszynski et al., 1998). Neuregulin reduces whole-cell NMDAR currents in cortical pyramidal neurons and decreases NMDAR-mediated EPSCs in cortical slices. This effect is blocked by an ErbB receptor tyrosine kinase inhibitor, a PLC inhibitor, an $\mathrm{IP}_{3}$ receptor antagonist, or $\mathrm{Ca}^{2+}$ chelators, and by agents that interfere with actin polymerization, but not by microtubular blockers (Gu et al., 2005). Injection of BAPTA in oocytes to a 5 $\mathrm{mM}$ intracellular concentration blocked the ACh modulation of NMDA currents in our experiments (NR1/2A current after ACh application $105 \pm 2 \%$ compared with the current before ACh application, $n=5$ ) (compare with ACh data of Fig. $2 A$ ). We also found that injection of phalloidin $(1 \mu \mathrm{M})$ attenuated the AChinduced inhibition (ACh-inhibited NR1/2B current in control cells, $60.5 \pm 6 \%$ of the current before, $n=7$; ACh-inhibited current in phalloidin cells, $74.2 \pm 6.9 \%$ of the current before, $n=$ $3)$, whereas microtubular inhibitors did not (data not shown). Although we used ACh instead of EGF in these experiments, these pathways similarly regulate NMDA currents in oocytes (Figs. 2-4). It is therefore possible that our effects are accompanied by a rearrangement of the actin cytoskeleton.

Recent studies suggest that impaired glutamatergic transmission and especially reduced NMDAR activity underlie the pathogenesis of schizophrenia (Konradi and Heckers, 2003). EGF administration in rats induces various behavioral hallmarks of schizophrenia (Futamura et al., 2003). In addition, EGFR expression is found upregulated in forebrain regions of schizophrenics (Futamura et al., 2002). Our data may provide potential mechanistic insights on how EGF impairs glutamatergic transmission.

In neurons, one main route for PLC $\gamma$ activation is provided by Trk neurotrophin receptor tyrosine kinases (Huang and Reichardt, 2003). Brain-derived neurotrophic factor has been shown to regulate phosphorylation of NR2B subunits via TrkB 
(Levine et al., 1998; Lin et al., 1999). Future models may be able to predict NMDAR state by consolidating the efficacy of each synaptic pathway for altering phosphorylation, $\mathrm{Ca}^{2+}$ levels, $\mathrm{PIP}_{2}$ levels, and other synaptic modulatory signals.

\section{References}

Balla T (1998) Phosphatidylinositol 4-kinases. Biochim Biophys Acta 1436:69-85.

Buonanno A, Fischbach GD (2001) Neuregulin and ErbB receptor signaling pathways in the nervous system. Curr Opin Neurobiol 11:287-296.

Cochet C, Filhol O, Payrastre B, Hunter T, Gill GN (1991) Interaction between the epidermal growth factor receptor and phosphoinositide kinases. J Biol Chem 266:637-644.

Ding WG, Toyoda F, Matsuura H (2004) Regulation of cardiac IKs potassium current by membrane phosphatidylinositol 4,5-bisphosphate. J Biol Chem 279:50726-50734.

Dingledine R, Borges K, Bowie D, Traynelis SF (1999) The glutamate receptor ion channels. Pharmacol Rev 51:7-61.

Du X, Zhang H, Lopes C, Mirshahi T, Rohacs T, Logothetis DE (2004) Characteristic interactions with phosphatidylinositol 4,5-bisphosphate determine regulation of kir channels by diverse modulators. J Biol Chem 279:37271-37281.

Ehlers MD (2003) Activity level controls postsynaptic composition and signaling via the ubiquitin-proteasome system. Nat Neurosci 6:231-242.

Ehlers MD, Zhang S, Bernhadt JP, Huganir RL (1996) Inactivation of NMDA receptors by direct interaction of calmodulin with the NR1 subunit. Cell 84:745-755.

Fukami K, Furuhashi K, Inagaki M, Endo T, Hatano S, Takenawa T (1992) Requirement of phosphatidylinositol 4,5-bisphosphate for alpha-actinin function. Nature 359:150-152.

Fukami K, Sawada N, Endo T, Takenawa T (1996) Identification of a phosphatidylinositol 4,5-bisphosphate-binding site in chicken skeletal muscle $\alpha$-actinin. J Biol Chem 271:2646-2650.

Futamura T, Toyooka K, Iritani S, Niizato K, Nakamura R, Tsuchiya K, Someya T, Kakita A, Takahashi H, Nawa H (2002) Abnormal expression of epidermal growth factor and its receptor in the forebrain and serum of schizophrenic patients. Mol Psychiatry 7:673-682.

Futamura T, Kakita A, Tohmi M, Sotoyama H, Takahashi H, Nawa H (2003) Neonatal perturbation of neurotrophic signaling results in abnormal sensorimotor gating and social interaction in adults: implication for epidermal growth factor in cognitive development. Mol Psychiatry [Erratum (2003) 8:565] 8:19-29.

Gamper N, Reznikov V, Yamada Y, Yang J, Shapiro MS (2004) Phosphatidylinositol 4,5-bisphosphate signals underlie receptor-specific $\mathrm{G}_{\mathrm{q}} / 11$ mediated modulation of N-type $\mathrm{Ca}^{2+}$ channels. J Neurosci [Erratum (2005) 25:1 p following 757] 24:10980-10992.

Garcia RA, Vasudevan K, Buonanno A (2000) The neuregulin receptor ErbB-4 interacts with PDZ-containing proteins at neuronal synapses. Proc Natl Acad Sci USA 97:3596-3601.

Gerecke KM, Wyss JM, Karavanova I, Buonanno A, Carroll SL (2001) ErbB transmembrane tyrosine kinase receptors are differentially expressed throughout the adult rat central nervous system. J Comp Neurol 433:86-100.

Goldin AL (1992) Maintenance of Xenopus laevis and oocyte injection. Methods Enzymol 207:266-279.

Gu Z, Jiang Q, Fu AK, Ip NY, Yan Z (2005) Regulation of NMDA receptors by neuregulin signaling in prefrontal cortex. J Neurosci 25:4974-4984.

Gurd JW, Bissoon N (1997) The N-methyl-D-aspartate receptor subunits NR2A and NR2B bind to the SH2 domains of phospholipase C- $\gamma$. J Neurochem 69:623-630.

Hendricks KB, Wang BQ, Schnieders EA, Thorner J (1999) Yeast homologue of neuronal frequenin is a regulator of phosphatidylinositol-4-OH kinase. Nat Cell Biol 1:234-241.

Holden C (2003) Psychiatric drugs. Excited by glutamate. Science 300:1866-1868

Huang EJ, Reichardt LF (2003) Trk receptors: roles in neuronal signal transduction. Annu Rev Biochem 72:609-642.

Hughes S, Marsh SJ, Tinker A, Brown DA (2007) PIP $_{2}$-dependent inhibition of M-type (Kv7.2/7.3) potassium channels: direct on-line assessment of $\mathrm{PIP}_{2}$ depletion by Gq-coupled receptors in single living neurons. Pflügers Arch, in press.

Husi H, Ward MA, Choudhary JS, Blackstock WP, Grant SG (2000) Pro- teomic analysis of NMDA receptor-adhesion protein signaling complexes. Nat Neurosci 3:661-669.

Kim HK, Kim JW, Zilberstein A, Margolis B, Kim JG, Schlessinger J, Rhee SG (1991) PDGF stimulation of inositol phospholipid hydrolysis requires PLC-gamma 1 phosphorylation on tyrosine residues 783 and 1254 . Cell 65:435-441.

Kobrinsky E, Mirshahi T, Zhang H, Jin T, Logothetis DE (2000) Receptormediated hydrolysis of plasma membrane messenger PIP2 leads to $\mathrm{K}^{+}$current desensitization. Nat Cell Biol 2:507-514.

Koizumi S, Rosa P, Willars GB, Challiss RA, Taverna E, Francolini M, Bootman MD, Lipp P, Inoue K, Roder J, Jeromin A (2002) Mechanisms underlying the neuronal calcium sensor-1-evoked enhancement of exocytosis in PC12 cells. J Biol Chem 277:30315-30324.

Konradi C, Heckers S (2003) Molecular aspects of glutamate dysregulation: implications for schizophrenia and its treatment. Pharmacol Ther 97:153-179.

Kornau HC, Schenker LT, Kennedy MB, Seeburg PH (1995) Domain interaction between NMDA receptor subunits and the postsynaptic density protein PSD-95. Science 269:1737-1740.

Krauter T, Ruppersberg JP, Baukrowitz T (2001) Phospholipids as modulators of K(ATP) channels: distinct mechanisms for control of sensitivity to sulphonylureas, $\mathrm{K}^{+}$channel openers, and ATP. Mol Pharmacol 59:1086-1093.

Krupp JJ, Vissel B, Heinemann SF, Westbrook GL (1996) Calciumdependent inactivation of recombinant $N$-methyl-D-aspartate receptors is NR2 subunit specific. Mol Pharmacol 50:1680-1688.

Krupp JJ, Vissel B, Thomas CG, Heinemann SF, Westbrook GL (1999) Interactions of calmodulin and alpha-actinin with the NR1 subunit modulate $\mathrm{Ca}^{2+}$-dependent inactivation of NMDA receptors. J Neurosci 19:1165-1178.

Lan JY, Skeberdis VA, Jover T, Grooms SY, Lin Y, Araneda RC, Zheng X, Bennett MV, Zukin RS (2001) Protein kinase C modulates NMDA receptor trafficking and gating. Nat Neurosci 4:382-390.

Legendre P, Rosenmund C, Westbrook GL (1993) Inactivation of NMDA channels in cultured hippocampal neurons by intracellular calcium. J Neurosci 13:674-684.

Lei S, Czerwinska E, Czerwinski W, Walsh MP, MacDonald JF (2001) Regulation of NMDA receptor activity by F-actin and myosin light chain kinase. J Neurosci 21:8464-8472.

Leonard AS, Hell JW (1997) Cyclic AMP-dependent protein kinase and protein kinase $\mathrm{C}$ phosphorylate $\mathrm{N}$-methyl-D-aspartate receptors at different sites. J Biol Chem 272:12107-12115.

Leonard AS, Bayer KU, Merrill MA, Lim IA, Shea MA, Schulman H, Hell JW (2002) Regulation of calcium/calmodulin-dependent protein kinase II docking to $N$-methyl-D-aspartate receptors by calcium/calmodulin and $\alpha$-actinin. J Biol Chem 277:48441-48448.

Levine ES, Crozier RA, Black IB, Plummer MR (1998) Brain-derived neurotrophic factor modulates hippocampal synaptic transmission by increasing $N$-methyl-D-aspartic acid receptor activity. Proc Natl Acad Sci USA 95:10235-10239.

Li BS, Sun MK, Zhang L, Takahashi S, Ma W, Vinade L, Kulkarni AB, Brady RO, Pant HC (2001) Regulation of NMDA receptors by cyclindependent kinase-5. Proc Natl Acad Sci USA 98:12742-12747.

Liao GY, Wagner DA, Hsu MH, Leonard JP (2001) Evidence for direct protein kinase-C mediated modulation of $N$-methyl-D-aspartate receptor current. Mol Pharmacol 59:960-964.

Lieberman DN, Mody I (1994) Regulation of NMDA channel function by endogenous $\mathrm{Ca}^{2+}$-dependent phosphatase. Nature 369:235-239.

Lin SY, Wu K, Len GW, Xu JL, Levine ES, Suen PC, Mount HT, Black IB (1999) Brain-derived neurotrophic factor enhances association of protein tyrosine phosphatase PTP1D with the NMDA receptor subunit NR2B in the cortical postsynaptic density. Brain Res Mol Brain Res $70: 18-25$

Logothetis DE, Movahedi S, Satler C, Lindpaintner K, Nadal-Ginard B (1992) Incremental reductions of positive charge within the S4 region of a voltage-gated $\mathrm{K}^{+}$channel result in corresponding decreases in gating charge. Neuron 8:531-540.

MacDonald JF, Kotecha SA, Lu WY, Jackson MF (2001) Convergence of PKC-dependent kinase signal cascades on NMDA receptors. Curr Drug Targets 2:299-312.

Mayer ML, Vyklicky Jr L, Clements J (1989) Regulation of NMDA receptor 
desensitization in mouse hippocampal neurons by glycine. Nature 338:425-427.

McLaughlin S, Murray D (2005) Plasma membrane phosphoinositide organization by protein electrostatics. Nature 438:605-611.

Mullner C, Vorobiov D, Bera AK, Uezono Y, Yakubovich D, FrohnwieserSteinecker B, Dascal N, Schreibmayer W (2000) Heterologous facilitation of $\mathrm{G}$ protein-activated $\mathrm{K}^{+}$channels by beta-adrenergic stimulation via cAMP-dependent protein kinase. J Gen Physiol 115:547-558.

Nakanishi S, Catt KJ, Balla T (1995) A wortmannin-sensitive phosphatidylinositol 4-kinase that regulates hormone-sensitive pools of inositolphospholipids. Proc Natl Acad Sci USA 92:5317-5321.

Omkumar RV, Kiely MJ, Rosenstein AJ, Min KT, Kennedy MB (1996) Identification of a phosphorylation site for calcium/calmodulin-dependent protein kinase II in the NR2B subunit of the $N$-methyl-D-aspartate receptor. J Biol Chem 271:31670-31678.

Pian P, Bucchi A, DeCostanzo A, Robinson RB, Siegelbaum SA (2007) Modulation of cyclic-nucleotide-regulated $\mathrm{HCN}$ channels by $\mathrm{PIP}_{2}$ and its role in signaling through receptors couple to phospholipase C. Pflügers Arch, in press.

Raucher D, Stauffer T, Chen W, Shen K, Guo S, York JD, Sheetz MP, Meyer T (2000) Phosphatidylinositol 4,5-bisphosphate functions as a second messenger that regulates cytoskeleton-plasma membrane adhesion. Cell 100:221-228.

Rhee SG, Bae YS (1997) Regulation of phosphoinositide-specific phospholipase C isozymes. J Biol Chem 272:15045-15048.

Rohacs T, Lopes CMB, Jin T, Ramdya P, Molnar Z, Logothetis DE (2003) Specificity of activation by phosphoinositides determines lipid regulation of Kir channels. Proc Natl Acad Sci USA 100:745-750.

Sather W, Johnson JW, Henderson G, Ascher P (1990) Glycine-insensitive desensitization of NMDA responses in cultured mouse embryonic neurons. Neuron 4:725-731.

Scott DB, Blanpied TA, Swanson GT, Zhang C, Ehlers MD (2001) An NMDA receptor ER retention signal regulated by phosphorylation and alternative splicing. J Neurosci 21:3063-3072.

Scott DB, Michailidis I, Mu Y, Logothetis D, Ehlers MD (2004) Endocytosis and degradative sorting of NMDA receptors by conserved membraneproximal signals. J Neurosci 24:7096-7109.

Stauffer TP, Ahn S, Meyer T (1998) Receptor-induced transient reduction in plasma membrane PtdIns(4,5)P2 concentration monitored in living cells. Curr Biol 8:343-346.

Suh BC, Hille B (2005) Regulation of ion channels by phosphatidylinositol 4,5-bisphosphate. Curr Opin Neurobiol 15:370-378.

Toker A (1998) The synthesis and cellular roles of phosphatidylinositol 4,5bisphosphate. Curr Opin Cell Biol 10:254-261. van der Wal J, Habets R, Varnai P, Balla T, Jalink K (2001) Monitoring agonist-induced phospholipase $\mathrm{C}$ activation in live cells by fluorescence resonance energy transfer. J Biol Chem 276:15337-15344.

van Rossum D, Kuhse J, Betz H (1999) Dynamic interaction between soluble tubulin and C-terminal domains of $N$-methyl-D-aspartate receptor subunits. J Neurochem 72:962-973.

Wang LY, Orser BA, Brautigan DL, MacDonald JF (1994) Regulation of NMDA receptors in cultured hippocampal neurons by protein phosphatases 1 and 2A. Nature 369:230-232.

Wang YT, Salter MW (1994) Regulation of NMDA receptors by tyrosine kinases and phosphatases. Nature 369:233-235.

Weber W (1999) Ion currents of Xenopus laevis oocytes: state of the art. Biochim Biophys Acta 1421:213-233.

Wechsler A, Teichberg VI (1998) Brain spectrin binding to the NMDA receptor is regulated by phosphorylation, calcium and calmodulin. EMBO J 17:3931-3939.

Willars GB, Nahorski SR, Challiss RA (1998) Differential regulation of muscarinic acetylcholine receptor-sensitive polyphosphoinositide pools and consequences for signaling in human neuroblastoma cells. J Biol Chem 273:5037-5046.

Wyszynski M, Lin J, Rao A, Nigh E, Beggs AH, Craig AM, Sheng M (1997) Competitive binding of alpha-actinin and calmodulin to the NMDA receptor. Nature 385:439-442.

Wyszynski M, Kharazia V, Shanghvi R, Rao A, Beggs AH, Craig AM, Weinberg R, Sheng M (1998) Differential regional expression and ultrastructural localization of $\alpha$-actinin-2, a putative NMDA receptor-anchoring protein, in rat brain. J Neurosci 18:1383-1392.

Xu C, Watras J, Loew LM (2003) Kinetic analysis of receptor-activated phosphoinositide turnover. J Cell Biol 161:779-791.

Young P, Gautel M (2000) The interaction of titin and alpha-actinin is controlled by a phospholipid-regulated intramolecular pseudoligand mechanism. EMBO J 19:6331-6340.

Zhang S, Ehlers MD, Bernhardt JP, Su CT, Huganir RL (1998) Calmodulin mediates calcium-dependent inactivation of $N$-methyl-D-aspartate receptors. Neuron 21:443-453.

Zhao X, Varnai P, Tuymetova G, Balla A, Toth ZE, Oker-Blom C, Roder J, Jeromin A, Balla T (2001) Interaction of neuronal calcium sensor-1 (NCS-1) with phosphatidylinositol 4-kinase beta stimulates lipid kinase activity and affects membrane trafficking in COS-7 cells. J Biol Chem 276:40183-40189.

Zukin RS, Bennett MV (1995) Alternatively spliced isoforms of the NMDARI receptor subunit. Trends Neurosci 18:306-313. 